\title{
Zika virus infection
}

\author{
Derek R. MacFadden MD, Isaac I. Bogoch MD
}

CMAJ Podcasts: author interview at https://soundcloud.com/cmajpodcasts/151486-five

\section{Zika virus is transmitted through mosquito bites and typically causes asymptomatic infection or mild symptoms in most people}

The symptoms of Zika virus infection may last up to one week and include a maculopapular rash, fever, joint and muscle pain, and conjunctivitis. ${ }^{1,2}$ Previous outbreaks in the Pacific Islands and the current outbreak have indicated a potential association with neurologic illnesses such as GuillainBarré syndrome. ${ }^{1,2}$

People travelling to affected areas should protect themselves from mosquito bites

People planning to travel to Central and South America, the Caribbean and Mexico can stay up to date on the changing geographic distribution of the Zika virus through online resources. ${ }^{4}$ Infection can be prevented by wearing protective clothing such as long-sleeved shirts and long pants and by using insect repellants containing DEET (diethyltoluamide) or icaridin, also known as picaridin. ${ }^{4,5}$

CMAJ invites submissions to "Five things to know about ..." Submit manuscripts online at http://mc.manuscriptcentral .com/cmaj

\section{Zika virus has spread rapidly via bites from infected Aedes mosquitoes}

Since its identification in Brazil in May 2015, Zika virus has spread through many countries in South and Central America, the Caribbean and Mexico. ${ }^{3}$ Aedes mosquitoes, found globally in tropical and subtropical regions, bite during the day and are particularly active during dawn and dusk (Figure 1). These mosquitoes also transmit dengue and chikungunya viruses. These infections, along with malaria, should be considered in febrile travellers returning from affected regions.

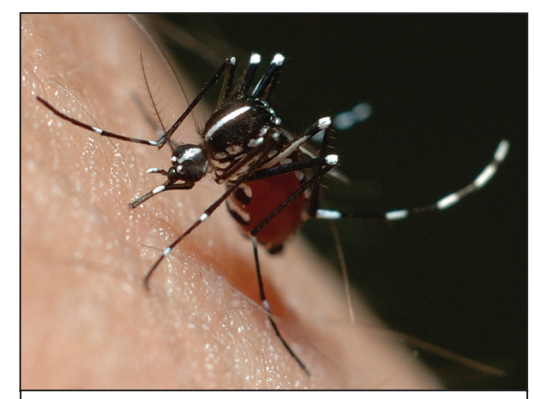

Figure 1: Aedes aegypti mosquitoes transmit Zika virus.

\section{Treatment of Zika virus infection is supportive}

The diagnosis of Zika virus infection is based on results of serum polymerase chain reaction or serologic testing. ${ }^{4,5}$ Acetaminophen can be used to relieve the fever and pain associated with infection. ${ }^{4,5}$

\section{References}

1. Cardoso CW, Paploski IAD, Kikuti M, et al. Outbreak of acute exanthematous illness associated with Zika, chikungunya, and dengue viruses, Salvador, Brazil. Emerg Infect Dis 2015;21:2274-6.

2. Musso D, Nilles EJ, Cao-Lormeau VM. Rapid spread of emerging Zika virus in the Pacific area. Clin Microbiol Infect 2014;20:O595-6.

3. Bogoch II, Brady OJ, Kraemer MU, et al. Anticipating the international spread of Zika virus from Brazil. Lancet 2016 Jan. 14 [Epub ahead of print].

4. Zika virus updates. Atlanta: US Centers for Disease Control and Prevention; 2016. Available: www.cdc.gov/zika (accessed 2016 Jan. 15).

5. Zika virus travel advisory. Ottawa: Public Health Agency of Canada; 2016. Available: www.phac -aspc.gc.ca/phn-asp/2016/zika-eng.php (accessed 2016 Jan. 15).
A potential link between Zika virus infection in pregnant women and congenital microcephaly in newborns is under investigation

Although the potential association between Zika virus infection and microcephaly is being investigated, the Public Health Agency of Canada has cautioned pregnant women and women considering becoming pregnant to assess their risk and consider postponing travel to affected areas and to use individual protection measures to prevent mosquito bites should they choose to travel. ${ }^{5}$

Competing interests: None declared.

This article has been peer reviewed.

Affiliations: Division of Infectious Diseases (MacFadden, Bogoch), University of Toronto, Toronto, Ont.; Harvard T.H. Chan School of Public Health (MacFadden), Harvard University, Boston, Mass.

Correspondence to: Derek MacFadden, derek.macfadden@mail.utoronto.ca

CMAJ 2016. DOI:10.1503/cmaj.151486 